\title{
Complete genome sequence and construction of an infectious full-length cDNA clone of a cucumber vein yellowing virus (CVYV) isolate from Portugal
}

\author{
K. Cordes ${ }^{1} \cdot$ E. Maiss ${ }^{1} \cdot$ S. Winter ${ }^{2} \cdot$ H. Rose ${ }^{1}$ (D)
}

Received: 27 May 2021 / Accepted: 7 August 2021 / Published online: 4 October 2021

(c) The Author(s) 2021

\begin{abstract}
Cucumber vein yellowing virus (CVYV) is a member of the genus Ipomovirus in the family Potyviridae. In the National Center for Biotechnology Information (NCBI) database, three complete genome sequences of CVYV isolates from Spain (NC_006941), Israel (KT276369), and Jordan (JF460793) are available. In this study, we report the complete sequence of an isolate of CVYV from Portugal (DSMZ PV-0776) along with the construction of an infectious full-length cDNA clone via Gibson assembly. The sequence of CVYV Portugal shows the closest relationship to a CVYV isolate from Spain (genome, 99.7\% identity; polyprotein, 99.7\% identity). The CVYV full-length cDNA clone was introduced by electroporation into Rhizobium radiobacter and infiltrated into the cotyledons of Cucumis sativus plantlets, resulting in symptoms resembling those of the wild-type virus. Transmission of the infectious CVYV full-length clone by the whitefly Bemisia tabaci was confirmed. This first report confirming the infectivity of a CVYV cDNA clone provides the opportunity to study gene functions in a consistent genomic background.
\end{abstract}

Cucumber vein yellowing virus (CVYV) is a member of the genus Ipomovirus in the family Potyviridae. This genus includes seven species (ICTV Master Species List 2020.v1 [MSL36]). The first description of CVYV was published by Cohen and Nitzany in 1960 in Israel [1], and the virus has since been reported in the Middle East (Lebanon [2], Turkey [3], Jordan [4], Cyprus [5], and Iran [6]), Europe (Portugal [7], Spain [8], and France [9]) and Africa (Sudan [10] and Tunisia [11]). CVYV infects mainly plants in the family Cucurbitaceae, such as cultivated cucumber (Cucumis sativus), squash (Cucurbita pepo), melon (Cucumis melo),

Handling Editor: Ralf Georg Dietzgen.

The CVYV Portugal DSMZ PV-0776 full-length clone sequence has been included in the NCBI database with the accession number MZ130935.

H. Rose

rose@ipp.uni-hannover.de

1 Institute of Horticultural Production Systems, Dept Phytomedicine, Leibniz Universität Hannover, Herrenhäuser Str. 2, 30419 Hannover, Germany

2 Leibniz Institute DSMZ, German Collection of Microorganisms and Cell Cultures, Inhoffenstraße 7 B, 38124 Braunschweig, Germany bottle gourd (Lagenaria siceraria), and watermelon (Citrullus lanatus) [12] as well as wild-growing cucurbits [13]. Symptoms are mainly described as yellowing of veins and leaves, stunting [1,3], and, in the case of melons, fruit splitting [7]. Other experimental host plants that do not belong to the family Cucurbitaceae, including chervil (Anthriscus cerefolium, Apiaceae), tobacco (Nicotiana clevelandii, Solanaceae), tomato (Solanum lycopersicum, Solanaceae), and jimsonweed (Datura stramonium, Solanaceae) have also been reported to be infected [14]. In studies on weed species growing near or in greenhouses in Spain, the virus was also found in field bindweed (Convolvulus arvensis, Convolvulaceae), mallow (Malva parviflora, Malvaceae), and common sow thistle (Sonchus oleraceus, Asteraceae) [15]. In nature, CVYV is transmitted by the whitefly Bemisia tabaci in a semi-persistent manner, while the virus is also transmitted mechanically [16]. Like other potyvirids, ipomoviruses have a monopartite single-stranded positive-sense RNA genome, which has a genome-linked viral protein (VPg) covalently bound to the 5' end and a polyadenylated 3' end [17]. This genus is separated into three subgroups, according to their genome organization. In the $\mathrm{N}$-terminal region, sweet potato mild mottle virus (SPMMV) [18] and tomato mild mottle virus (TMMoV) [19] contain P1 and HC-Pro; CVYV, squash vein yellowing virus (SqVYV) $[20,21]$ and 


\section{CVYV DSMZ PV-0776 genome}

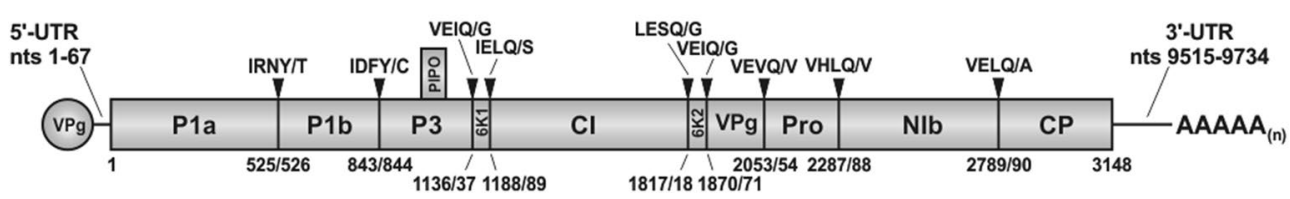

Fig. 1 Schematic diagram of the genome organization of cucumber vein yellowing virus (CVYV) DSMZ PV-0776. Arrows indicate positions of cleavage sites. UTR, untranslated region; nts, nucleotides; aa,

coccinia mottle virus (CocMoV) [22] encode a duplicated $\mathrm{P} 1$ region (P1a and $\mathrm{P} 1 \mathrm{~b})$; and cassava brown streak virus CBSV) and Ugandan cassava brown streak virus (UCBSV) have a P1 but neither a P1b nor an HC-Pro. The latter additionally encode a HAM1h domain between NIb and CP $[23,24]$. Other proteins encoded are P3 (including PIPO [pretty interesting Potyviridae ORF]), 6K1, CI (cylindrical inclusion), 6K2, NIa-VPg (nuclear inclusion protein a-viral protein, genome-linked), NIa-Pro (nuclear inclusion protein a-protease), NIb (nuclear inclusion protein b, RNA-dependent RNA polymerase [RdRp]) and CP (coat protein) [17]. To date, there are three complete genome sequences of CVYV isolates available in the NCBI database: one from Spain (ALM32, NC_006941.1), one from Jordan (JF460793.1), and one from Israel (ISM, KT276369).

In this study, the complete genome sequence of an isolate of CVYV from Portugal (DSMZ PV-0776) was determined, and an infectious full-length cDNA clone was constructed. Sequence analysis revealed a high level of sequence identity $(99.7 \%)$ when its nucleotide and encoded amino acid sequence were compared to those of CVYV from Spain (NC_006941.1).

At the Leibniz Institute DSMZ Plant Virus Department, cucumber plantlets (C. sativus cv. 'Vorgebirgstraube') that were naturally infected with CVYV PV-0776 served as the source of CVYV. The virus was further propagated in cucumber, and freshly infected plants were used to prepare dsRNA extracts at 15 days post-inoculation (dpi) [25]. Primers for the construction of a full-length cDNA clone were derived from the sequence of the isolate from Spain (NC_006941.1) and are listed in Supplementary Table S1. For the construction of an infectious full-length cDNA clone via Gibson assembly [26], the genome of CVYV was amplified as two fragments (without poly(A)) and integrated into the binary vector pDIVA (KX665539). A detailed cloning procedure is provided in the supplementary material. The cloned CVYV genome was sequenced and found to be 9734 nucleotides (nt) in length, with a large open reading frame extending from nt 68 to 9511 and terminated by a UGA stop codon (nt 9512-9414). Nucleotides 1-67 represent the 5'untranslated region (UTR) and nt 9515 to 9734 , the amino acids; PIPO, pretty interesting Potyviridae open reading frame; CI, cylindrical inclusion protein; VPg, viral protein, genome-linked; Pro, protease; $\mathrm{NIb}$, nuclear inclusion protein $\mathrm{b}$; $\mathrm{CP}$, coat protein

3'-UTR (without poly(A)). PIPO starts at nucleotide position 2989 with the conserved motif $\mathrm{GA}_{7}$ and ends at position 3228 with UAA, resulting in a protein of 77 amino acids $(\sim 9 \mathrm{kDa})$. When compared to the other available complete sequences, percent identity values for the complete genome/ polyprotein are $99.7 \% / 99.7 \%$ (vs. Spain), $94.3 \% / 96.1 \%$ (vs. Israel), and $94.4 \% / 96.1 \%$ (vs. Jordan), indicating the closest relationship to the isolate from Spain. In total, there are 36 nucleotide substitutions, resulting in eleven amino acid changes when compared to the isolate from Spain. The amino acid changes are located in P1a (four exchanges), P1b (two exchanges), NIa-Pro (two exchanges), and NIb (three exchanges). For detailed information, see Supplementary Table S2. A schematic representation of the genome of CVYV Portugal is shown in Figure 1.

The full-length cDNA clone was transformed into Rhizobium radiobacter $\mathrm{GV} 2260$ by electroporation and infiltrated into the lower surface of the cotyledons of four C. sativus $\mathrm{cv}$. 'Vorgebirgstraube' plantlets using a needleless syringe. The $\mathrm{OD}_{600}$ in the inoculation buffer was adjusted to $1.0 \pm 0.2$. In all plants, symptoms occurred 19-21 dpi resembling those of the wild type (Fig. 2), and the virus was confirmed by specific RT-PCR. For detailed information, see "Infiltration of the full-length cDNA clone and verification of CVYV infection" in the supplementary material.

Semi-persistent transmission of the CVYV full-length clone by B. tabaci MEAM1 pol 63 [27] was confirmed at the Leibniz Institute DSMZ Plant Virus Department. The whiteflies (20-30 adults) were allowed to feed on infected donor plants (C. sativus cv. 'Riesenschael') for different lengths of time to determine the acquisition access and inoculation time. The CVYV full-length clone was readily transmitted. Efficient virus transmission was observed when whiteflies were kept overnight on infected plants. However, a two-hour acquisition/inoculation period was found to be sufficient for transmission of the CVYV full-length clone. Virus symptoms became noticeable 14 days after whitefly transmission and were similar to those of the wild-type virus isolate from Portugal.

CVYV Portugal is the first reported infectious and transmissible full-length cDNA clone of a virus isolate of the 


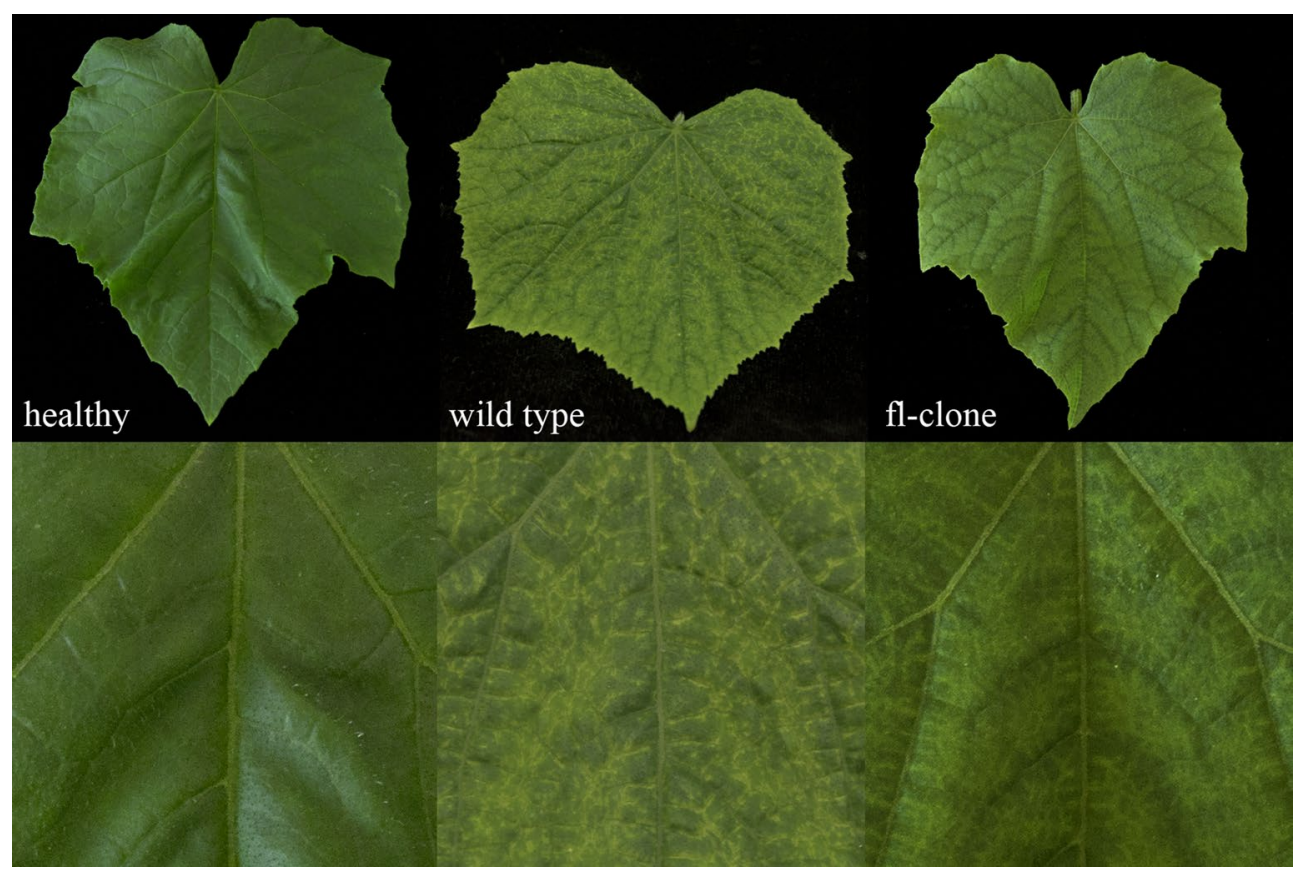

Fig. 2 Symptom expression of cucumber vein yellowing virus (CVYV) DSMZ PV-0776 wild type-virus (16 dpi) and full-length cDNA clone (15 dpi) compared to an untreated healthy control in systemic leaves of C. sativus cv. 'Vorgebirgstraube'. Top, whole leaves; bottom, detail

species Cucumber vein yellowing virus. This now provides the possibility to introduce genome modifications to study vital biological virus traits, transmission, symptomatology, and host range.

Supplementary Information The online version contains supplementary material available at https://doi.org/10.1007/s00705-021-05248-y.

Acknowledgements We thank Birgit Milde for excellent technical assistance, and Dr. Wulf Menzel for providing CVYV-infected cucumber plantlets. Furthermore, we would like to thank Beate Stein for the Bemisia tabaci transmission.

Funding Open Access funding enabled and organized by Projekt DEAL.

Availability of data and material The manuscript has data included as electronic supplementary material.

\section{Declarations}

Conflict of interest The authors declare that they have no conflict of interest.

Ethical approval This article does not contain any studies with human participants or animals performed by any of the authors.

Open Access This article is licensed under a Creative Commons Attribution 4.0 International License, which permits use, sharing, adaptation, distribution and reproduction in any medium or format, as long as you give appropriate credit to the original author(s) and the source, provide a link to the Creative Commons licence, and indicate if changes were made. The images or other third party material in this article are included in the article's Creative Commons licence, unless indicated otherwise in a credit line to the material. If material is not included in the article's Creative Commons licence and your intended use is not permitted by statutory regulation or exceeds the permitted use, you will need to obtain permission directly from the copyright holder. To view a copy of this licence, visit http://creativecommons.org/licenses/by/4.0/.

\section{References}

1. Cohen S, Nitzany FE (1960) A whitefly transmitted virus of cucurbits in Israel. Phytopathol Mediterr 1:44-46

2. Abrahamian PE, Sobh H, Seblani R et al (2013) First Report of Cucumber vein yellowing virus on cucumber in Lebanon. Plant Dis 97:1516

3. Yilmaz MA (1989) Cucumber vein yellowing virus in Cucurbitaceae in Turkey. Plant Dis 73:610

4. Al-Musa AM, Qusus SJ, Mansour AN (1985) Cucumber vein yellowing virus on cucumber in Jordan. Plant Dis 69:361

5. Papayiannis LC, Ioannou N, Boubourakas IN et al (2005) Incidence of viruses infecting cucurbits in Cyprus. J Phytopathol 153:530-535

6. Bananej K, Desbiez C, Girard M et al (2006) First report of Cucumber vein yellowing virus on cucumber, melon, and watermelon in Iran. Plant Dis 90:1113

7. Louro D, Quinot A, Neto E et al (2004) Occurrence of Cucumber vein yellowing virus in cucurbitaceous species in southern Portugal. Plant Pathol 53:241

8. Cuadrado IM, Janssen D, Velasco L et al (2001) First Report of Cucumber vein yellowing virus in Spain. Plant Dis 85:336 
9. Lecoq H, Dufour O, Wipf-Scheibel C et al (2007) First Report of Cucumber vein yellowing virus in melon in France. Plant Dis 91:909

10. Desbiez C, Caciagli P, Wipf-Scheibel C et al (2019) Evidence for long-term prevalence of cucumber vein yellowing virus in Sudan and genetic variation of the virus in Sudan and the Mediterranean Basin. Plant Pathol 68:1268-1275

11. Yakoubi S, Desbiez C, Fakhfakh H et al. (2007) Occurrence of Cucurbit yellow stunting disorder virus and Cucumber vein yellowing virus in Tunisia. J Plant Pathol 89:417-420

12. Mansour A, Al-Musa A (1993) Cucumber vein yellowing virus; host range and virus vector relationships. J Phytopathol 137:73-78

13. Al-Musa AM (1989) Oversummering hosts for some cucurbit viruses in the Jordan Valley. J Phytopathol 127:49-54

14. Morris J, Steel E, Smith P et al (2006) Host range studies for Tomato chlorosis virus, and Cucumber vein yellowing virus transmitted by Bemisia tabaci (Gennadius). Eur J Plant Pathol 114:265-273

15. Janssen D, Ruiz L, Velasco L et al (2002) Non-cucurbitaceous weed species shown to be natural hosts of Cucumber vein yellowing virus in south-eastern Spain. Plant Pathol 51:797

16. Harpaz I, Cohen S (1965) Semipersistent relationship between Cucumber vein yellowing virus (CVYV) and its vector, the tobacco whitefly (Bemisia tabaci Gennadi us). J Phytopathol $54: 240-248$

17. Wylie SJ, Adams M, Chalam C et al (2017) ICTV Virus Taxonomy Profile: Potyviridae. J Gen Virol 98:352-354

18. Colinet D, Kummert J, Lepoivre P (1998) The nucleotide sequence and genome organization of the whitefly transmitted sweetpotato mild mottle virus: a close relationship with members of the family Potyviridae. Virus Res 53:187-196

19. Walkey DGA, Spence NJ, Clay CM et al (1994) A potyvirus isolated from solanaceous hosts. Plant Pathol 43:931-937
20. Adkins S, Webb SE, Achor D et al (2007) Identification and characterization of a novel whitefly-transmitted member of the family Potyviridae isolated from cucurbits in Florida. Phytopathol 97:145-154

21. Li W, Hilf ME, Webb SE et al (2008) Presence of P1b and absence of HC-Pro in Squash vein yellowing virus suggests a general feature of the genus Ipomovirus in the family Potyviridae. Virus Res 135:213-219

22. Desbiez C, Verdin E, Tepfer M et al (2016) Characterization of a new cucurbit-infecting ipomovirus from Sudan. Arch Virol 161:2913-2915

23. Monger WA, Seal S, Isaac AM et al (2001) Molecular characterization of the Cassava brown streak virus coat protein. Plant Pathol 50:527-534

24. Monger WA, Alicai T, Ndunguru J et al (2010) The complete genome sequence of the Tanzanian strain of Cassava brown streak virus and comparison with the Ugandan strain sequence. Arch Virol 155:429-433

25. Morris TJ (1979) Isolation and analysis of double-stranded RNA from virus-infected plant and fungal tissue. Phytopathol 69:854

26. Gibson DG, Young L, Chuang R-Y et al (2009) Enzymatic assembly of DNA molecules up to several hundred kilobases. Nat Methods 6:343-345

27. Kollenberg M, Winter S, Götz M (2014) Quantification and localization of Watermelon chlorotic stunt virus and Tomato yellow leaf curl virus (Geminiviridae) in populations of Bemisia tabaci (Hemiptera, Aleyrodidae) with differential virus transmission characteristics. PLoS ONE 9:e111968

Publisher's Note Springer Nature remains neutral with regard to jurisdictional claims in published maps and institutional affiliations. 